\title{
The High Tide in Jiangsu: A Perspective from Local Sources of the Time*
}

\section{Robert Ash}

\begin{abstract}
This essay is an attempt to recreate the events of 1955-57 - the "high tide" of co-operativization - in a single province of China (Jiangsu). Whereas the other articles in this Special Issue of The China Quarterly view the same events with the benefits of hindsight, as provided by documentary materials and other evidence that have become available since the end of the Mao Era, the account given here is based on contemporary reports - above all, provincial press reports. The intention is thereby not only to give a flavour of the extraordinary atmosphere that surrounded one province's response to Mao's 31 July 1955 speech, but also to convey the tensions and policy dilemmas that emerged during the second half of the year and into 1956. Even allowing for the bias of official media reports, the evidence and analysis presented here vividly highlight the complex factors - economic and social - bearing on policy making and policy implementation during 1955-56.
\end{abstract}

During the 1950s, a series of institutional upheavals changed the fabric of China's rural society and economy. The culmination of this process was the incorporation of virtually the entire farm population into rural people's communes during the Great Leap Forward of 1958. The existence of a line of continuity that runs through these institutional changes is one of the important findings of several pathbreaking studies published since the early 1990s on the basis of previously classified Chinese-language materials. ${ }^{1}$ Notwithstanding Bachman's emphasis on coalitional politics ${ }^{2}$ as the institutional basis of policy-making in the 1950 s, the consensus view of the recent studies is that the real arbiter of major policy decisions was Mao Zedong. From this perspective, there is a clear link between Mao's

* I am grateful to Professor Christopher Howe for having encouraged me to re-visit, after a gap of more than 30 years, the High Tide in Jiangsu. I am well aware of the dangers of relying solely on sources contemporary with the events of 1955-57. But part of the purpose of this article is to show that a careful reading of such sources can yield useful insights to set alongside the findings of materials from the post-Mao period.

1. E.g. see Frederick C. Teiwes and Warren Sun (eds.), The Politics of Agricultural Co-operativization in China: Mao, Deng Zihui, and the "High Tide" of 1955 (Armonk: M.E. Sharpe, 1993); Frederick C. Teiwes and Warren Sun, China's Road to Disaster: Mao Central Politicians and Provincial Leaders in the Unfolding of the Great Leap Forward, 1955-1959 (Armonk: M.E. Sharpe, 1999); and Alfred L. Chan, Mao's Crusade: Politics and Policy Implementation in China's Great Leap Forward (Oxford: Oxford University Press, 2001).

2. In particular, the manoeuvring between two bureaucratic factions, the "finance coalition" and the "planning and heavy industry coalition": see David Bachman, Bureaucracy, Economy and Leadership in China: The Institutional Origins of the Great Leap Forward (Cambridge: Cambridge University Press, 1991).

(c) The China Quarterly, 2006 doi: 10.1017/S0305741006000361 
condemnation of those who had adopted a stance of fanmaojin (反冒进) (opposing rash advance) in 1953 and 1955, and his endorsement of the principles of duohao kuaisheng (多好快省) (more, better, faster, more economical $)^{3}$ that were at the heart not only of the Great Leap Forward but also of the "first leap forward" in 1956. The origins and course of the High Tide of agricultural co-operativization (1955-56) are part of a continuum of events stretching from the first land reform (1949-52) to what ultimately proved to be an abortive search for "agrarian radicalism"

This article does not seek to embrace this entire continuum of agricultural institutional change. On the contrary, it focuses on the much shorter period of the High Tide proper - that is, on the events of 1955-57, during which most Chinese farmers were incorporated at breathtaking speed into fully socialist and centrally managed collectives. It examines only the immediate impact of the tectonic shift that removed, at least until the early 1980s, the traditional household basis of agriculture and re-defined the organizational framework in which farming took place. The analysis is limited to the experience of one province - Jiangsu - as seen through the prism of contemporary reports, drawn overwhelmingly from the local provincial newspaper.

\section{The High Tide in Jiangsu}

The extraordinary events that took place throughout China during 1955-56 have their immediate origin in a characteristic change of mind by Mao, in this case about the most desirable pace of cooperativization. Between March and May 1955, Mao shifted his ground from endorsement of a policy of cautious advance to a call for accelerated co-operativization. In Hangzhou on 17 May, he addressed a conference of Party secretaries from 15 provinces and municipalities, and set a target of one million agricultural producer co-operatives (APCs) in China by the end of 1956 - a third of them to be established in seven key provinces (including Jiangsu). ${ }^{5}$ In Jiangsu itself, the new policy guidelines were reaffirmed at a meeting of Party officials (also in May), who called for a doubling in the number of APCs in the

3. This phrase was first used by Zhou Enlai and Bo Yibo at a briefing conference at the end of 1955. It was adopted as a formal slogan in an editorial in Renmin ribao (People's Daily) on 1 January 1956.

4. See David Zweig, Agrarian Radicalism in China, 1968-1981 (Cambridge, MA: Harvard University Press, 1989).

5. The following month, Mao pressed for a further increase in the national target to 1.3 million, although this was resisted by Deng Zihui at an acrimonious meeting. On 11 July Deng came under further attack from Mao, who described the rural work department, of which Deng was director, as being "rightist and short of enthusiasm" (Teiwes and Sun, The Politics of Agricultural Co-operativization, p. 13). In contrast to the rural work department, the ministry of agriculture fell into line with Mao's position. 
province by spring $1956 .^{6}$ The acceleration in the pace of cooperativization in the province was justified by the supposed success of existing co-operatives north and south of the Chang [Yangtze], 90 per cent of which were said to have achieved output levels above those recorded by mutual-aid teams and individual farmers.

The single event which precipitated the national High Tide was Mao's speech "On the question of agricultural co-operativization," which he delivered in Beijing to another conference of provincial Party secretaries on 31 July $1955^{7}$ In Jiangsu, the response to the speech was overwhelming, and within a year the organizational framework of farming in the province had been transformed from small-scale, essentially family-based operations to large-scale production by fully-socialist collectives. ${ }^{8}$ Indeed, the transition to collective agriculture in the province was even more rapid than in both China as a whole and the east China region of which Jiangsu was part. In mid1955 a mere 11 per cent of Jiangsu's farm households had joined lower-level co-ops, and not a single collective existed. ${ }^{9}$ A year later, almost all households were involved in a variant of co-operative farming, the vast majority of them in fully-socialist collectives.

Initially, the most rapid expansion of co-operatives took place in northern Huaiyin (淮阴) and Yangzhou (扬州) prefectures (zhuanqu 专区), whereas the slowest progress was recorded in Suzhou prefecture in the south. Intra-provincial regional differences partly reflected greater enthusiasm for APCs by farmers in poorer areas such

6. The target was for 67,591 lower-level APCs, embracing about $25 \%$ of all farm households, to be established by the time of spring ploughing 1956. In addition, 136,000 "backbone cadres" would be trained in order to manage the accelerated establishment of co-operatives. See Nanjing Xinhua ribao (New China Daily - hereafter $X H R B$ ), 4 June 1953, p.1. $X H R B$ was the main daily newspaper of Jiangsu.

7. Kenneth R. Walker, "Collectivization in retrospect: the "Socialist High Tide" of autumn 1955-spring 1956," The China Quarterly, No. 26 (1966) contains a detailed analysis of Mao's speech and is still a classic point of reference for anyone interested in the rationale and impact of co-operativization in China. See also Teiwes and Sun, The Politics of Agricultural Co-operativization, which, in addition to the perceptive introduction, makes available translations of key Chinese documentation relating to the High Tide, released in the 1980s.

8. Between mid-1955 and mid-1956, the proportion of farm households in Jiangsu belonging to APCs rose from $11.2 \%$ to $96.4 \%$ (in fully-socialist collectives, from $0.7 \%$ to $78.9 \%$ ) (Shi Jingtang et al. (eds.), Zhongguo nongye hezuohua yundong shihliao (Source Materials on the Agricultural Co-operativization Movement in China) (Beijing: Tongji chubanshe, 1957), Vol. 2, pp. 1011-19). Detailed provincial reports show that semi-socialist co-operativization in Jiangsu took place in two phases: first, in September-October 1955, when membership rose from $18 \%$ to $49 \%$ of all farm households; second, in December 1955-January 1956, when it increased from about half to $84 \%$ (see $X H R B, 25$ September, 1 and 29 October 1955, 21 January 1956, and Changzhou gongren bao (Changzhou Workers' Daily), 2 February 1956). At the end of January 1956, the Jiangsu Provincial Party Committee issued a directive calling for the trial establishment of collectives, and by February fully-socialist collectivization was well under way. The subsequent pace of advance was frenetic. Indeed, in the absence of a new Agricultural Tax Law, in June the Jiangsu authorities were forced to introduce temporary regulations to facilitate the collection of agricultural taxes.

9. Throughout this article I use "co-operative" to refer to the lower-level, semisocialist APC; "collective," to refer to its higher level, fully-socialist form. 
as Huaiyin than by those in richer areas such as Suzhou, who feared that co-operative farming might reduce output and income. ${ }^{10}$ These differing perceptions were the source of some of the most intractable problems faced by APCs in Jiangsu. One report noted that poor farmers were being excluded from co-operatives throughout the province. ${ }^{11}$ In a village in Huaiyin county, almost half of all poor farmers seeking co-operative membership were refused admission; in Jurong (句容) county, 30 middle farmers refused to admit ten poor farmers to an APC. Such action was motivated by concerns that poor farmers' lack of capital would impede rises in productivity and improvements in living standards. The only concession offered to the poor farmers was an undertaking to let them apply for membership after two years. ${ }^{12}$ Significantly, in January 1956, provincial authorities approved a cash loan of over 40 million yuan to poor co-operatives to help resolve problems faced by poor farmers who were unable to afford the financial contributions that were due to the APCs. ${ }^{13}$

Meanwhile, cadres found themselves in a difficult position. Some were condemned for displaying "rightist-conservative" attitudes towards socialization; others for complacency - "blind satisfaction" - with what had been achieved; and still others for displaying "onesidedness" (pianmianxing 片面性) in their over-zealous implementation of the official "class line" in favour of poor farmers. Political pressures to create more APCs, regardless of objective conditions, were intense and interfered with farm work. Such tensions sometimes generated a vicious circle. The faster the pace of co-operativization the more likely that farm work would be neglected, and in turn the less likely that output and income would rise, thereby threatening disillusionment with the new institutional structure. ${ }^{14}$

\section{The Impact of the High Tide in Jiangsu}

The expected benefits of APCs derived from unified planning and management of agricultural operations on an increasingly large scale. Better and more extensive land utilization would facilitate more

10. As one upper-middle farmer put it, "I have a good life working on my own. When other farmers' land fails, mine still produces something. I don't want to join them [poorer farmers]. I'll wait 2 or 3 years and then see how things look ..." (Shi Jingtang et al., Source Materials on the Agricultural Co-operativization Movement, Vol. 2, pp. 605-606).

11. XHRB, 25 September 1955.

12. Similar reports were forthcoming from Yancheng prefecture, where poor farmers spoke resentfully about cadres who "suspected the poor and loved the rich." The situation was reportedly made worse by infiltration of APCs by subversive elements - landlords, rich farmers and "counter-revolutionaries" (see XHRB, 15 and 25 September, and 14 and 26 October 1955; also Shanghai, Jiefang ribao, 24 November 1955).

13. Liu Dinghan (ed.), Jiangsu sheng da shiji, 1949-1985 (A Chronology of Jiangsu) (Jiangsu: Jiangsu sheng renmin chubanshe, 1988), p.113.

14. Hence the decision of the Jiangsu Provincial Party Committee, in October 1955, to halt temporarily the further expansion of co-operatives and direct attention towards urgent production tasks in the fields (XHRB, 26 October 1955). 
rational cropping patterns, including the extension of multiple cropping. More effective and specialized use of labour would generate efficiency improvements, while mass labour mobilization would enable co-operatives to undertake large-scale fixed capital formation (land reclamation and water control) beyond the capacity of farmers working on their own. Since the APCs sought to maximize the use of labour rather than the value of a work point, it was argued that labour could also be employed up to the point at which its marginal product approached zero. A more diversified rural economy was also expected to emerge out of collective farming.

Contemporary reports suggest that increased provincial output ${ }^{15}$ in APCs came from the more effective use of land and labour, and enhanced technical progress - soil improvements, deeper ploughing and sowing, and higher fertilizer applications. However, universally positive plaudits during 1956 were heavily qualified in subsequent reports. It is clear, for example, that as the pace of institutional change quickened, so technical demands were raised to unreasonable levels, and insufficient attention was given to local conditions and climatic constraints in implementing official policy. A letter purporting to come from a Jiangsu peasant claimed that technical changes had been forced on farmers during 1956 and complained that wheat had been allowed to rot in the fields because so much time had been used in trying to carry out ill-understood technical improvements. ${ }^{16}$

The larger scale of farming does seem to have facilitated a more rational use of resources. In contrast to farmers' previous preoccupation with "planting whatever they needed for personal consumption," co-ops were applauded for moving production closer to a pattern that reflected comparative advantage. ${ }^{17}$ Some 435,000 hectares of land were shifted from glutinous to non-glutinous rice production. Perhaps most noteworthy, even if initial claims were exaggerated, was the extension of double cropping by collectives. In many parts of south Jiangsu, a high man-land ratio and intensive cultivation techniques left little scope for extending the arable area. Output growth therefore depended critically on raising yields, and increasing multiple cropping was one way of achieving this. ${ }^{18}$

Centralized land and labour management in increasingly large farm units $^{19}$ promised to facilitate infrastructural improvements by

15. Assessing, let alone measuring, the economic impact of the High Tide through analysis of annual changes in sown area, yields and total output is to my mind unhelpful. Such changes reflect climatic conditions (in Jiangsu, very good in 1955, but very bad in 1956), as well as policy factors separate from the establishment of APCs (e.g. the introduction, in spring 1955, of the "three fix" [san ding] scheme).

16. XHRB, 13 January 1957.

17. $X H R B, 13$ and 24 September 1955.

18. In Kunshan county, the multiple cropping index was raised from 175 to 192 , and in Siyang county from 150 to 200 between 1955 and 1957 (XHRB, 5 and 10 December 1957).

19. As of mid-1956, the average size of fully-socialist collectives in Jiangsu was 429 households, compared with 69 in semi-socialist co-operatives. 
enabling collectives to undertake large-scale construction projects. According to one report, in January-May 1956 irrigation construction was 70 per cent greater than that of the previous three years, as a result of which the provincial irrigated area was extended by 590,000 hectares. $^{20}$ The importance of water control in a province that was highly susceptible to natural disasters ${ }^{21}$ is self evident. But the gains were not costless, and it was later admitted that a lack of proper planning by collective authorities had undermined the effectiveness of water conservation and other construction work. ${ }^{22}$

Through their mobilizational capacities, the impact of APCs on employment was significant. In Wuxi (无锡) county, co-operatives helped raise the number of adult male work days by 35 per cent from $130-150$ per year to $180-200 .^{23}$ In an early established collective in Jiangning (江寧) county, the number of work days per unit labour rose from 75 (1953) to 173 (1955), while wage payments increased from 1.00 yuan to 1.73 yuan per labour day. ${ }^{24}$ Similar claims were made on behalf of collectives set up in the white heat of the High Tide itself. For example, in Songjiang (松江) (south Jiangsu) and Suining (睢寧) (north) counties, work attendance rates apparently rose markedly. ${ }^{25}$ But the increase in labour supply was far from a panacea. On the one hand, there is evidence that the extension of double cropping was limited, sometimes seriously, by labour shortages. ${ }^{26} \mathrm{On}$ the other hand, labour surpluses also emerged in some areas, which encouraged farmers to abandon the land in search of more productive work elsewhere. Although female labour participation often increased - not least in important jobs such as collecting organic fertilizer, transplanting rice seedlings and harvesting the wheat - it was also sometimes curtailed to accommodate the increased supply of men.

Collectivization in Jiangsu took a severe toll on draught animals, the most important source of transport and tractive power in the rural sector. Deliberately killing animals was probably rare; the more serious problem was that of neglect after they were taken into collective care. $^{27}$ In an attempt to alleviate shortages, 250 draught animal markets were established in 26 counties, and in 1957 officials

20. $X H R B, 1$ January 1957.

21. Floods severely affected $1.3 \mathrm{~m}$ ha. of land in Jiangsu in 1954; in 1956, $2.7 \mathrm{~m}$ ha. were inundated.

22. $X H R B, 9$ February 1957.

23. $X H R B, 8$ January 1956.

24. $X H R B, 26$ January 1956.

25. $X H R B, 14$ and 28 January 1957. In the suburbs of Shanghai, farmers' work rates increased by $20-40 \%$ in 1956. Shanghai, Xinwen ribao (Daily News), 17 January 1957.

26. E.g. data in Ministry of Agriculture, Mechanization Bureau, Zhongguo nongye jijiehua wenti (Problems of Farm Mechanization in China), Baoding, 1958, pp. 213-17, indicate serious labour deficits facing attempts to extend double cropped rice and wheat in Suzhou prefecture, and a rotation pattern of rice, wheat and cotton in Nantong prefecture.

27. Animals were ill-fed and watered, poorly housed and over-worked. See $X H R B$, 18 and 24 February, and 8 and 13 March 1957. 
were sent to Anhui in order to purchase 5,000 animals. ${ }^{28}$ Calculations show that the average arable area burden per draught animal had reached 67 hectares by 1957 - the highest figure in the whole of China and far in excess of any animal's physical capacity. ${ }^{29}$

The impact of the High Tide on rural income in Jiangsu is difficult to gauge. An authoritative source shows that between 1955 and 1956 average provincial per capita income fell by 27 per cent from 68.5 to 49.8 yuan. But a sharp deterioration in natural conditions may have been just as responsible for this decline as the ill-effects of the APCs if not more so. In 1957, income recovered to a level (67 yuan) marginally below that of bumper-harvest $1955 .{ }^{30}$ The most interesting comment on changes in provincial rural income was contained a report by Fei Xiaotong (費孝通), who in 1956 returned to the south Jiangsu village (Kaixiangong 开弦弓) that had been the subject of his famous 1936 study. ${ }^{31}$ His findings were not calculated to please the authorities, for they indicated that farm incomes in 1956 were a mere 5 per cent above those of 20 years earlier, leading him to conclude that "no major advances have been made in raising Chinese farmers" incomes.",32

Mao's decision to accelerate farm socialization partly reflected his concern about persistent rural income disparities, and part of the rebuttal of Fei's study was based on his failure to take account of changes in income distribution under the impact of the High Tide. Semi-socialist co-operative farming had by no means eliminated income gaps - indeed, the binary income distribution system discriminated against resource-poor farmers who were dependent on wage labour, but favoured well-off farmers, who benefited additionally from dividend payments for capital (draught animals, tools, land) used by the co-operatives. ${ }^{33}$ Working capital was often taken into cooperative use with precipitate haste. ${ }^{34}$ Some ("mostly middle") Jiangsu farmers refused to join APCs because of uncertainty about future rental payments, ${ }^{35}$ and fears that tools and draught animals handed over to co-operatives would be mismanaged.

\section{XHRB, 9 March 1957.}

29. See Nongcun gongzuo tongxun (Rural Work Report), 1957, No. 8, pp. 22-23.

30. Huadong nongye kexue tongbao (East China Bulletin of Agricultural Science), No. 2 (1958).

31. Peasant Life in China (Oxford and New York: Oxford University Press, 1936).

32. See $X H R B, 5$ September 1957. The findings were strongly rebutted and Fei himself was condemned as a "rightist" who had deliberately falsified the material basis of his study.

33. The crucial difference between lower-level and higher-level APCs lay in the manner of income distribution. In a semi-socialist APC, income derived from wages to labour, and from dividends payable to owners of land and capital which they had contributed to the co-operative. In a fully-socialist APC, the rental element was abolished, and collective members were rewarded entirely on the basis of the work they performed on behalf of the collective. (The text of regulations governing APCs can be found in Xinhua banyuekan (New China Semi-Monthly), No. 88 (1956).)

34. XHRB, 18 September 1955.

35. See Zhongguo nongcun di shehui zhuyi gaochao (The Socialist High Tide in China's Villages), 3 vols. (1956), Vol. 2, p. 593. 
The case of a co-operative in Liyang (溧阳) county, Zhenjiang (镇 江) prefecture, illustrates the difficulties of achieving a distribution system acceptable to all parties. The decision to distribute 55 per cent of net farm income as wages to labour and 45 per cent as dividends on land led middle farmers to complain of discrimination against aboveaverage landowners. A counter-proposal to introduce a 50:50 wagerental ratio led poor member farmers to claim infringement of their interests. Their complaint was upheld by a review, which argued that a 50:50 distribution system would reduce the value of a work point to 5 kilograms of rice - less than poor farmers' earnings from part-time work. In the end, a new formula was adopted that allocated 38 per cent of household income on the basis of land holdings (implying a reduction of almost a quarter in land dividends), and 62 per cent on that of labour effort (a rise of well over 20 per cent in the value of a labour day).

One way of overcoming such difficulties, especially for hard-pressed and barely numerate cadres, was to press ahead more quickly with fully-socialist collectivization, which was lauded for its ability to end class stratification in the province through the abolition of private ownership. ${ }^{36}$ The most representative investigation of the impact of collectivization on rural class structure argued that through improvements in farm and subsidiary income, collectivization had greatly reduced the number of peasants living in straitened circumstances and raised many to middle peasant status. ${ }^{37}$ Even so, regional income gaps within Jiangsu remained considerable. In 1956, for example, three of the eight prefectures enjoyed per capita net income levels that were between 40 and 60 per cent higher than the provincial averages, while in the remaining five they were $11-40$ per cent below that figure. ${ }^{38}$

From the perspective of Beijing, a major part of the argument for accelerated farm socialization lay in the greater control it afforded the government in extracting the agricultural surplus - above all, that of grain. As early as March 1957, there were complaints about the high content of water and impurities in 750,000 tons of grain purchased in Jiangsu, and concern that the reopening of free markets would disrupt state purchases of farm and subsidiary products. ${ }^{39}$ But the true scale of the crisis did not emerge until the summer, when it became clear that grain acquisition targets were not being fulfilled. ${ }^{40}$ Natural disasters of the previous year had already compelled the state to reduce planned grain deliveries in the province by 20 per cent, in addition to which surplus grain areas were demanding to retain more

36. XHRB, 6 and 7 January and 30 September 1957.

37. XHRB, 30 September 1957.

38. Rural Work Report, 1957, No.4, p. 4. The gap between the highest (Songjiang and Suzhou) and lowest (Huaiyin) prefectural average per capita incomes was almost $180 \%$. The difference is not attributable to the impact of 1956 natural disasters, since the gap remained much the same in 1957

39. XHRB, 13 and 15 March 1957.

40. $X H R B, 10$ July 1957. 
grain to raise consumption levels. In early June, less than 10 per cent of planned grain acquisitions had been fulfilled, leading to complaints about farmers' "extravagance" and cadres' preoccupation with local welfare at the expense of state needs. ${ }^{41}$ Rich peasants and "evil elements" were made the scapegoats for excessive retentions by collectives, the emergence of black markets and increasing speculative activity in grain. ${ }^{42}$ Although the situation subsequently improved, summer grain purchases were almost 15 per cent lower than in 1956, despite a rise in output. Progress was also uneven: in August two prefectures - Nantong (南通) and Yancheng (盐城) - had barely fulfilled half of their quota targets. ${ }^{43}$

\section{Concluding Remarks}

Assessing the short-term effect of rural institutional changes in China in the 1950s is extremely difficult. For one thing, the impact was shaped by other, often unrelated, factors. For another, the changes - starting with land reform and ending with full communization - took place so rapidly that one phase of the sequential process had barely ended before the next was under way. In the High Tide, two phases - co-operativization and collectivization - closely overlapped one another.

The immediate response to Mao's July 1955 speech took place in a year blessed by exceptionally good weather in Jiangsu, and following the dangerous logic of proper hoc, ergo hoc, it was easy to attribute increased output that year to the beneficial effects of co-operativization. ${ }^{44}$ The same logic could be applied to events in 1956, when fully-socialist collectivization proceeded in the context of the most severe natural disasters that Jiangsu had encountered since 1949. Ironically, the impact of those disasters is likely to have been significantly mitigated by the mobilizational capacity of the collectives. Yet in the wake of declining output and income in 1956, many farmers began to call for a retreat from collectivization, and as early as January 1957 the deputy-secretary of the Jiangsu Party committee, Liu Shunyuan (刘 顺元), acknowledged farmers' disillusionment with the fully-socialist APCs. ${ }^{45}$

The supposed correlation between the right to withdraw from a collective and the incentives given to member farmers has been

41. XHRB, 12 July 1957.

42. $X H R B, 16$ and 26 July 1957.

43. XHRB, 14 August 1957.

44. Ironically, even collectives' attainment of higher output was sometimes interpreted negatively, as in Songjiang and Suzhou prefectures, where it was widely believed that collectives had already exhausted their potential and "production has reached a ceiling" (shengchan dao ding) (XHRB, 8 and 24 February 1957).

45. XHRB, 6, 7 and 16 January 1957. Disillusionment among APC members was reflected in demands for greater state assistance to resolve collectives' economic problems (e.g. see $X H R B, 11,13$ and 15 March 1957). 
debated elsewhere. ${ }^{46}$ My own reading of sources contemporary with the High Tide is that members were not prevented from withdrawing from collectives in Jiangsu (far from it: see below), but that an excessive preoccupation by cadres with institutional socialization did probably undermine production planning and policy implementation. ${ }^{47}$ There is little doubt too that the principle of voluntarism was frequently violated, as institutional change accelerated and co-ops were merged into collectives, or even set up ab initio.

The process of withdrawals from APCs gathered pace in Jiangsu in spring 1957. In May, farmers began to abandon collectives in Danyang (丹阳) county; in the worst instance, over 20 households withdrew in a single day. ${ }^{48}$ The sources of the defaulters' dissatisfaction were threefold: the lack of transparency in collective accounting, cadre selfishness and poor collective management (especially of tools and draught animals). Most dramatic of all was the withdrawal of 204 households from a collective in Tai county, leaving just nine poor peasant families to pursue collective production. ${ }^{49}$ Another sign of discontent was the "blind flow" of farmers out of villages into cities: in Nanjing (南京), Suzhou (苏州), Yangzhou (阳州) and Xuzhou (徐 州), illegal trading - sometimes by cadres - in food coupons was taking place ${ }^{50}$ Despite the launch of a rectification campaign, ${ }^{51}$ the problems persisted into the second half of the year, leading to accusations that subversive elements were stirring up trouble with libels such as that "the Communist Party has had a change of heart. At the time of Liberation, they handed out relief rice; now they won't even let you eat what you grow yourself" and "There's no advantage in collectivization ... Farmers' lives are very difficult, the state monopoly procurement system is in a mess, basic-level cadre unity has been shattered, and the Party no longer cares about the peasants." 52

It is idle to speculate what the impact of the High Tide would have been, had it adhered to the key principles of gradualism and voluntarism emphasized by Mao in his July 1955 speech. The

46. Justin Yifu Lin, "Collectivization and China's agricultural crisis in 1959-1961," Journal of Political Economy (JPE), Vol. 98, No. 6 (December 1990), pp. 1228-52; Xiao-yuan Dong and Gregory K. Dow, "Monitoring costs in Chinese agricultural teams," JPE, Vol. 101, No. 3 (June 1993), pp. 539-553; Dong and Dow, "Does free exit reduce shirking in production teams?" Journal of Comparative Economics, Vol. 17 (1993) (see also Justin Yifu Lin's response in ibid.).

47. Throughout 1957 agricultural operations in Jiangsu were behind schedule. Early in the year there were reports of wheat sprouts rotting at the root and dying; in June farmers were criticized for delaying rice transplanting; and in autumn they faced renewed criticism for carelessness in autumn sowing (XHRB, 21 February, 2 March, 22 June, 13 September and 16 October).

48. $X H R B, 13$ May 1957 (the title of this article is revealing: "Drive out dissatisfaction, distinguish clearly between what is right and wrong, and persevere with collectives").

49. XHRB, 13 September 1957.

50. XHRB, 22 May 1957.

51. Note the title of another article of the time: "Expose the erroneousness of the "three -isms"' (subjectivism, bureaucratism and sectarianism) (XHRB, 17 May 1957).

52. See XHRB, 27 August 1957, and Jiefang ribao, 29 and 30 August 1957. 
likelihood is that the scale of the difficulties which emerged in 1956 and 1957 would have been reduced and that economic gains would have been greater. ${ }^{53}$ Attention has already been drawn to the potentially distorting impact on perceptions resulting from the coincidence of a period of extraordinarily frenetic institutional change with one of extreme natural conditions - favourable in 1955, unfavourable in 1956. In addition, in both years preoccupation with rural socialization diverted attention from more mundane issues of farm production and led to neglect of work in the fields.

In the end, the investment bias against agriculture of the First FiveYear Plan left institutional change as a kind of deus ex machina, the implementation of which would somehow overcome objective resource and other constraints and facilitate sustained farm output growth. In fact, many of the problems facing agriculture were the product of agronomic, demographic and economic factors, and were not susceptible to a one-dimensional institutional solution. What was needed was not a reorganization of existing patterns of farming but the creation of new ones. In the event, the government was unwilling, or unable, to recognize this reality. In the last months of 1957 a new policy for agriculture began to emerge, based on further involution. A significant event was the publication of a revised version of the 12Year Plan for Agriculture. Almost immediately, the targets set out in this document were adopted as short-term goals. The stage was set for the next, and greatest, Maoist adventure - the Great Leap Forward.

53. This is not to ignore the dangers of class polarization and increasing capitalist tendencies that might have attended a more sober pace of advance, thereby precipitating even more intractable problems. 